\title{
METODE ISTINBAT DALAM KITAB TAWDIH AL-AHKAM MIN BULUGH AL-MARAM KARYA AL-BASSAM (1346-1423 H)
}

\author{
Parlindungan Simbolon
}

Sekolah Tinggi Ilmu Tarbiyah al-Kifayah Riau e-mail: lindsimbolon@yahoo.com

\begin{abstract}
\begin{tabular}{|l|l|l|}
\hline Diterima: 23-04--2020 & Direvisi: 31-05-2020 & Dipublish: 29-06-2020 \\
\hline
\end{tabular}
Abstract: The tittle of this research is Istinbat Methods in The Book of Tawdih al-Ahkam Min Bulugh alMaram was Written By al-Bassam (1346-1423 H). al-Bassam is one of the contemporary Islamic scholar that has succeed in Hadith and Istinbat of the law in his book. Tawdih al-Abkam Min Bulugh al-Maram, before istinbat, al Bassam had arranged Hadith into its tittle (thematic) and then explained the quality of Hadith and its words. The main problem of this research: how are steps and methods of istinbat al-Bassam? How is istinbat of al-Bassam for ikbtilaf problems?. This research is aimed to find out steps and methods of istinbat al-Bassam in law, istinbat al-Bassam in ikbtilaf problems and istinbat al-Bassam toward contemporary problems. The data of this research was collected through library research that emphasize on textual study. And then the data was analyzed by using content analysis to get the conclusion. This research has found out that al-Bassam before istinbat of law, he had arranged Hadith based on its tittle and explained quality and its words. Al-Bassam did istinbat of law from the Hadith by using bayani and istislabi method. And then dealing with ikhtilaf al-Bassam was used to methods' 'ard al-aqwal, munaqasyah al-adillah and al-tariih.
\end{abstract}

Kata kunci: Istinbat, al-Bassam, Tawdih al-Ahkam

\section{PENDAHULUAN}

$\boldsymbol{H}$ ukum Islam bersumber dari kitabullah (al-Qur'an) dan sunnah Rasulullah SAW. Kitabullah adalah kalam Allah SWT yang diturunkan kepada Nabi Muhammad SAW yang ditulis dalam mushaf, diriwayatkan secara mutawatir dan bernilai ibadah bagi orang yang membacanya al-muta'abbad bitilawatih. (AlZarqani, n.d.) Sedangkan Sunnah Rasulullah atau Hadis adalah sesuatu yang dinisbahkan kepada Rasulullah SAW baik perkataan (qawl), perbuatan (fi'l) atau pengakuan (taqrir) (Al-Salih, 1984). Kitabullah dan Sunnah Rasulullah SAW menjadi sumber utama dalam perundangan Islam sebagaimana telah dijelaskan oleh Rasulullah SAW dalam Hadisnya yang artinya "aku tinggalkan kepadamu dua hal, bila kamu berpegang kepada keduanya kamu tidak akan tersesat selamnya". (Anas, n.d.)

Tidak semua pesan dan makna yang terkandung di dalam Hadis dapat dipahami dan diketahui dengan mudah, ini karena Hadis dalam menunjukkan hukum menggunakan berbagai cara, ada yang tegas dan ada yang tidak, ada yang hakikat dan ada pula yang majaz, sehingga memungkinkan banyak penafsiran. (Rahmawati., 2015) Pada sisi lain terdapat pula pertentangan antara satu 
Hadis dengan Hadis lain yang tentunya memerlukan penyelesaian. Oleh karena itu, untuk menangkap pesan dan makna yang tersembunyi dalam sebuah Hadis para ulama melakukan penggalian hukum melalui upaya ijtihad. Proses dan langkahlangkah kegiatan ijtihad melalui pemahaman dan penggalian hukum itulah yang disebut dengan metode penemuan hukum Islam, yang dalam istilah usul fiqih disebut dengan turuq al-ist\}inbat.(AlWahbi, n.d.)

Ijtihad dan kegiatan Istinbat hukum telah dilakukan bahkan sejak zaman Rasulullah SAW. Beliau sering melakukan ijtihad dan memerintahkan sahabat untuk melakukannya serta mengakui ijtihad mereka. (Yahya, 1986) Sahabat yang melakukan ijtihad ketika Rasulullah SAW

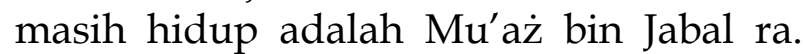
Hal ini dijelaskan dalam Hadis berikut:

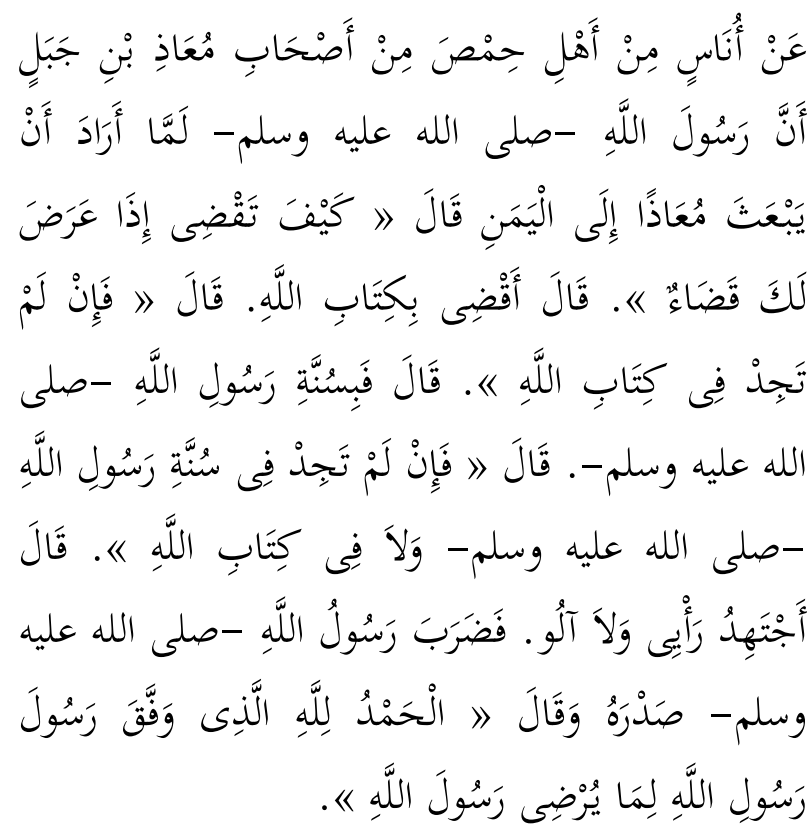

"Ketika Mu'aż bin Jabal diutus ke Yaman untuk berdakwah, Rasulullah saw bertanya: Dengan apa engkau akan memutuskan masalah? Mu'aż menjawab: Dengan alQur'an. Ditanya kembali: Jika tidak ada dalam al-Qur'an? Mu'aż menjawab: Aku akan menghukumi dengan sunnah Rasul. Ditanya kemabali: Jika tidak terdapat dalam al-Qur'an dan Sunnah? Mu'aż menjawab: Aku akan melakukan ijtihad. Kemudian Rasulullah saw. Menepuk dada Mu'aż dan mengatakan: Segala puji bagi Allah yang telah memberikan pemahaman kepada utusan Rasulullah". (Al-Asy'as, n.d.)

Setelah Rasulullah SAW wafat, para sahabatlah yang berperan untuk melakukan istinbat terhadap Hadis-Hadis Rasulullah SAW yang seterusnya dilanjutkan oleh para tabi'in. Kemudian ijtihad dan kegiatan istinbat hukum dari Hadis terus berlanjut dari abad ke abad hingga ke zaman kontemporer. Ini terbukti dengan munculnya berbagai macam dan ragam kitab syarah Hadis yang telah dihasilkan oleh para ulama.

Walaupun istinbat hukum dari Hadis telah dilakukan sejak dahulu, bukan berarti pintu istinbat sudah tertutup dan tidak bisa dilakukan lagi. Justru kegiatan istinbat harus tetap dilakukan dan dikembangkan untuk menjawab persoalan-persolan yang muncul di tengah masyarakat dengan membangkitkan dan mendorong berfikir secara rasional untuk mengembangkan hukum Islam secara proporsional. (Al-Kaf, 1998). Interpretasi dan istinbat hukum terhadap Hadis walaupun pada Hadis yang sama harus tetap dihidupkan untuk membuktikan bahwa Hadis sebagai salah satu sumber syari'at Islam tetap salih likulli zaman wa makan. (Al-Qardawi, 1993)

Untuk tujuan tersebut, para ulama kontemporer tetap melakukan syarah Hadis dan istinbat hukum dari kitab Hadis yang sudah dilakukan oleh ulama sebelumnya. Kitab Hadis hukum yang mendapat perhatian dari para ulama adalah kitab Bulugh al-Maram Min Adillah al-Ahkam yang ditulis oleh Ahmad bin 
Hajar al-'Asqalani (773-852 H). Kitab ini mendapat perhatian yang banyak dari kalangan para ulama kontemporer. Ini terbukti dengan munculnya banyak kitab syarah Hadis yang mensyarah HadisHadis dalam kitab tersebut.

'Abdullah bin 'Abdurrahman alBassam (1346 H-1423 H) adalah di antara ulama kontemporer yang telah mensyarah Hadis-Hadis dalam kitab Bulugh al-Maram dengan karyanya yang berjudul Tawdih al-Ahkam Min Bulugh al-Maram. Dalam kitab ini, al-Bassam mempersembahkan metode syarah Hadis yang menarik, tampilan dan pendekatannya berbeda dengan ulama lainnya, baik dari segi sistematika penulisan, syarah Hadis dan istinbat hukumnya.

Berdasarkan studi pendahuluan, penulis menemukan bahwa walaupun alBassam dinilai beraliran Hanbali, namun dalam menguraikan Hadis dan mengeluarkan hukum yang terkandung dalam Hadis pada kitab Tawdih al-Ahkam tidak terikat kepada satu imam dan tidak ta'assub (fanatik) kepada mażhab tertentu. Akan tetapi beliau menetapkan hukum berdasarkan dalil yang lebih kuat menurut pandangan para ulama. Jika berkaitan dengan masalah nawazil, alBassam menetapkan hukumnya dengan mengemukakan fatwa para ulama kontemporer.

Sebelum mensyarah Hadis, langkah pertama yang dilakukan al-Bassam adalah mentakhrij dan dan menjelaskan kualitas Hadis, kecuali Hadis tersebut diriwayatkan oleh Imam al-Bukhari dan Muslim atau salah satu di antara keduanya. Untuk menentukan kualitas Hadis apakah sahih, hasan atau da'if, al-Bassam mengemukakan komentar para ulama sebagai landasan penetapan kualitasnya. Ini menunjukkan bahwa al-Bassam adalah seorang ulama prolifik yang bukan hanya ahli dalam bidang fiqih tetapi juga menguasai ilmu Hadis.

Setelah menejelaskan kualitas Hadis, al-Bassam melanjutkan penjelasannya dengan menguraikan makna mufradat. Beliau menjelaskan lafazh-lafazh tertentu yang terkandung dalam Hadis bukan hanya dari segi maknanya tetapi juga dari segi gramatikanya. Penejelasan seperti ini terdapat pada setiap Hadis yang dimuat dalam kitab Bulugh al-Maram.

Setelah menjelaskan makna mufradat, seterusnya al-Bassam melakukan istinbat hukum yang terkandung dalam setiap Hadis. Bayan al-Ahkam dalam kitab Tawdih al-Ahkam ditandai dengan topik bahasan Ma Yu'khaż Min al-Hadis. Sesuatu yang menarik dari poin ini adalah al-Bassam menyimpulkan hukum dan hikmah dari Hadis dengan sangat luas dan sistematis dengan memberikan penomoran yang menunjukkan jumlah hukum ataupun hikmah yang diistinbatkan dari Hadis yang sedang disyarah. Inilah yang menarik untuk dikaji dari kitab Tawdih alAhkan Min Bulugh al-Maram karya alBassam.

Persoalan yang harus diselesaikan dalam penelitian ini adalah bagaimana langkah dan metode istinbat hukum alBassam dalam kitab Tawdih al-Ahkam Min Bulugh al-Maram? Bagaimana istinbat alBassam terhadap permasalahan-permasalahan fiqih (al-Ikhtilaf al-Fiqhiyah)?

\section{METODE PENELITIAN}

Penelitian ini merupakan penelitian maktabi (library research), yaitu penelitian 
yang datanya didapatkan berdasarkan studi kepustakaan seperti buku, ensiklopedi, jurnal, majalah dan dokumen lain yang berkaitan dengan penelitian. (Zed, 2008) penyajian data tidak dilakukan dengan menggunakan statistik sebagaimana lazimnya dalam penelitian kuantitatif. Secara metodologis, tata cara mengungkapkan pemikiran seseorang ataupun pandangan kelompok orang menggunakan penelitian kualitatif. Di antara pendekatan metode kualitatif adalah analisa isi. (Somantri, 2005). Artinya seorang peneliti berhadapan langsung dengan teks yang menjadi objektif penelitian. Pendekatan inilah yang digunakan dalam penelitian ini, yaitu meneliti dan menganalisa kitab Tawdih al-Ahkam karya al-Bassam dari segi metode istinbat hukumnya. Data primer dalam penelitian ini adalah kitab Tawdih al-Ahkam Min Bulugh al-Maram. Sedangkan data skundernya adalah buku, majalah, surat kabar dan website melalui akses internet

Setelah data didapatkan melalui proses metode pengumpulan data di atas, maka data-data tersebut dianalisis dan dikaji secara teliti dengan menggunakan teknik content analysis yaitu metode analisis ilmiah yang ditujukan kepada materi atau teks yang menjadi data dalam penelitian. (Muhajir, 1996) Dalam pengertian lain content analysis adalah suatu teknik yang digunakan untuk mendapatkan kesimpulan melalui usaha menemukan karakteristik pesan yang dilakukan secara objektif dan sistematis. (Soedjono, 1999)

\section{BIOGHRAFI 'ABDULLAH BIN 'ABDUR-RAHMAN AL-BASSAM}

Nama lengkap beliau adalah Syaikh 'Abdullah bin 'Abdurrahman bin Salih bin Hamd bin Muhammad bin Hamd bin Ibrahim al-Bassam al-Tamimi. Beliau dilahirkan di kota tempat tinggal keluarganya, yaitu 'Unaizah, Qasim, Saudi Arabia pada tahun 1346 H/1928 M. Beliau seorang ulama kontemporer yang dinilai bermazhab hanafi dan ber'aqidah Ahl al-Sunnah wa al-Jama'ah.(Al-Bassam, n.d.-b) Kepribadian dan keilmuan alBassam banyak dipengaruhi oleh gurunya Muhammad bin 'Abdul Wahhab 'Abdullah al-Qar'awi.(Al-Bassam, n.d.-b)

Pada masa kanak-kanak, 'Abdullah bin 'Abdurrahman al-Bassam belajar di berbagai sekolah (kuttab) yang ada di 'Unaizah. Sekolah terkenal yang pernah jadi tempat beajar al-Bassam adalah kuttab milik syaikh 'Abdullah bin Muhammad al-Qar'awi. Beliau belajar al-Qur'an dan pokok-pokok dasar ilmu syariah. Namun, dalam menghapal al-Qur'an beliau belajar kepada ayahnya. Setelah gurunya, alQar'awi meningalkan 'Unaizah dan berpindah ke wilayah bagian Selatan, maka beliau bersama kakaknya, syaikh Salih bin 'Abdurrahman al-Bassam belajar kepada ayahnya. Keduanya belajar alQur'an, tafsir, sirah nabawiyah, sejarah Islam, fiqih, dan tata bahasa Arab (Nahwu). Dalam bidang tafsir, beliau mempelajari Tafsir Ibn Kasir dan Tafsir alJalalayn, tentang fiqh, beliau belajar kitab Akhsar al-Mukhtasarat karya al-Balbani, dan tentang tata bahasa Arab beliau belajar Matn al-Jurumiyyah.

Saat masih belajar kepada syaikh alSa'di, beliau sudah diminta oleh masyarakat 'Unaizah untuk mengimami shalat tarawih dan tahajjud di bulan Ramadan 
dan memberikan ceramah motivasi pada sepuluh malam terakhir Ramadan. Sejak dibukanya Dar al-Tawhid di kota Ta'if, beliau melihat ada beberapa cabang ilmu yang tidak diajarkan gurunya. Beliau pun melakukan penelaahan terhadap apa yang beliau pelajari dari guru-gurunya.

Pada tahun $1365 \mathrm{H}$ beliau melakukan ibadah haji ke Mekkah. Di sana, beliau berjumpa dengan pembina Dar al-Tawhid, yaitu syaikh Muhammad bin 'Abdul 'Aziz. Di sana beliau memberikan kuliah yang membuat banyak masyarakat sangat terkesan atas materi dan metode penyampaian serta hafalannya. Al-Bassam berjumpa dengan para ulama senior, baik dari al-Azhar maupun yang lain yang juga mengajar di Dar alTawhid, seperti Syaikh 'Abdurrazzaq 'Afifi, syaikh Muhammad Husain alŻahabi, Syaikh 'Abdullah al-Salih alKhulaifi dan lain-lain.

\section{SISTEMATIKA PENULISAN KITAB TAWDIH AL-AHKAM}

Al-Bassam menulis kitab ini diawali dengan pembahasan beberapa asas penting yang harus diketahui oleh siapa saja yang ingin melakukan istinbat hukum dari sumber aslinya baik dari al-Qur'an maupun Hadits. Dalam hal ini, al-Bassam mengatakan setidaknya ada empat ilmu dasar yang mesti dikuasai, yaitu ilmu Mustalah al-Hadis, Usul al-Figh, al-Qawa'id al-Fiqhiyah dan al-Maqasid al-Syar'iyyah. Segala hal yang berkaitan dengan empat disiplin ilmu ini dijelaskan oleh al-Bassam secara mendalam pada bagian pendahuluan dalam kitab Tawdih al-Ahkam (AlBassam, 1423 H: 6). Masing-masing disiplin ilmu ini memiliki peran dan manfa'at tersendiri dalam mengistinbatkan hukum dari al-Qur'an dan Hadis.

Seterusnya al-Bassam melakukan syarah terhadap Hadis-Hadis dengan menjelaskan terlebih dahulu muqaddimah Ibnu Hajar dalam kitab Bulugh al-Maram. Pada muqaddimah tersebut dijelaskan istilah-istilah khusus yang menunjukkan ciri khas kitab Bulugh al-Maram seperti Rawah al-Sab'ah, Rawah al-Khamsah dan Muttafaq 'Alayh yang maksudnya adalah merujuk kepada nama perawi yang meriwayatkan dan menyusun kitab Hadis.

Al-Bassam menyusun kitab Tawdih al-Ahkam mengikuti sistematika penulisan Hadis-Hadis dalam kitab Bulugh alMaram. Dengan kata lain, susunan HadisHadis dalam kitab Tawdih al-Ahkam mengikut urutan Hadis-Hadis berdasarkan kitab dan bab yang disusun oleh Ibnu Hajar al-'Asqalani dalam kitab Bulugh alMaram.

Untuk membedakan antara matan dan syarah Hadis, al-Bassam meletakkan matan Hadis pada halaman bagian atas dalam kitab Tawdih al-Ahkam yang format tulisannya berbeda dengan syarahnya baik dari segi warna, bentuk dan ukurannya. Matan Hadis ditulis dengan warna hitam dan lebih tebal dari sanad, perawi dan syarahnya.

Hingga saat ini, kitab Tawdih alAhkam sudah dicetak sebanyak lima kali. Setiap kali cetak ulang selalu ada perobahan dan penambahan yang memperindah kemasannya untuk menarik minat para pembaca. Terkhusus pada terbitan kelima, al-Bassam mengatakan para pembaca pasti akan melihat perbedaan yang besar dengan terbitan sebelumnya. Ini karena pada terbitan kelima dikemas dengan rapi dan adanya 
penjelasan tambahan yang tidak ditemukan pada beberapa terbitan sebelumnya. (Al-Bassam, n.d.-b)

Penjelasan yang dimaksud sekaligus menjadi keunggulan kitab Tawdih alAhkam adalah adanya tambahan pembahasan beberapa permasalahan fiqih kontemporer yang disertai dengan fatwa ulama sebagai jawaban hukumnya, menjelaskan Takhriij al-Hadis yang disertai dengan analisis dan penjelasan kosa kata secara etimologi, serta kajian ilmu nahwu dan saraf serta analisis ilmiah.

Secara lebih ringkas, sistematika dan ciri khas penulisan kitab Tawdih al-Ahkam sebagaimana diungkapkan oleh al-Bassam seperti berikut:

a. Memisahkan sub-sub bahasan secara khusus

b. Tidak fanatik kepada satu mazhab

c. Memasukkan keputusan hukum yang dikeluarkan oleh Lembaga Komisi Fiqih Islam se Dunia

d. Menyesuaikan permasalahan hukum dengan riset ilmiah.

\section{LANGKAH DAN ISTINBAT HUKUM AL-BASSAM DALAM KITAB TAWDIH $A L-A H K A M$}

Hadis-Hadis yang dijadikan sample penelitian untuk mengetahui metode istinbat hukum al-Bassam dalam kitab Tawdih al-Ahkam adalah Hadis-Hadis yang terdapat pada Kitab al-Nikah. Pada Kitab alNikah terdapat empat belas bab atau sub bahasan, terdiri dari 173 Hadis. Semua Hadis-Hadis tersebut berkaitan dengan pernikahan.

Al-Bassam mengistinbatkan atau mengeluarkan hukum (istikhraj al-ahkam) dari Hadis dalam kitab Tawdih al-Ahkam dengan menggunakan langkah sebagai berikut: a. Mengelompokkan Hadis secara tematik

Sebelum melakukan istinbat dalam kitab Tawdih al-Ahkam, alBassam terlebih dahulu mengelompokkan Hadis-Hadis dalam satu kitab dan bab. Dalam hal ini, al-Bassam mengelompokkan Hadis-Hadis dimulai dari Kitab al-Taharah. Dalam kajian Ilmu Hadis, tipologi penulisan kitab seperti ini di-namakan kitab sunan, yaitu kitab Hadis yang ditulis oleh pengarangnya berdasarkan sistematika penulisan kitab dan bab ilmu fiqih.

Para ulama memulai tulisan mereka dengan Kitab al-Taharah bukan tanpa alasan dan tujuan. 'Abd al-'Aẑim Badawi misalnya menyatakan, taharah atau bersuci merupakan syarat sahnya ibadah, dengan demikian sesuatu yang menjadi syarat harus didahulukan dari yang disyaratkan (al-Syart Muqaddam 'Ala al-Masyrut.

Al-Bassam juga mengemukakan alasan kenapa sebuah kitab perlu dimulai dengan Kitab al-Taharah. Menurut beliau, taharah atau bersuci dari hadas dan najis merupakan syarat sahnya shalat, karena itu sesuatu yang menjadi syarat harus didahulukan (Syart al-Sya'i Yusbiquh).(Al-Bassam, n.d.-a) Seterusnya al-Bassam, menjelaskan topik atau sub bahasan baik menurut bahasa maupun istilah serta penjelasan lain yang berkaitan dengan pembahasan.

b. Menjelaskan kualitas Hadis

Langkah kedua yang dilakukan al-Bassam sebelum mengistinbatkan hukum adalah menjelaskan kualitas Hadis. Poin ini dalam kitab Tawdih alAhkam ditandai dengan topik darajah alHadis. Penjelasan kualitas Hadis dilakukan al-Bassam pada setiap Hadis 
kecuali Hadis yang diriwayatkan oleh Imam al-Bukhari dan Muslim atau salah satu dari keduanya (fi al-ahadis allati laisat fi al-sahihain aw ahadihima). Ini karena kesahihan Hadis tersebut telah disepakati oleh para ulama (muttafaq 'alaih).

Penjelasan seperti ini dilakukan al-Bassam dengan sangat cermat dan teliti sehingga beliau menemukan beberapa Hadis nama perawinya disebutkan oleh Ibn Hajar dalam Kitab Bulugh al-Maram, tetapi setelah ditakhrij Hadis tersebut tidak ditemukan dalam kitab asalnya. Sebagai contoh terdapat pada Hadis ke-28 pada Kitab al-Taharah, Bab al-Najasah dalam kitab Tawdih alAhkam sebagaimana pada Hadis dalam pernyataan al-Bassam berikut:

$$
\begin{aligned}
& \text { عن أبي هريرة رضي الله عنه قال : قالت خولة : يا } \\
& \text { رسول الله! فإن لم يذهب الدم؟قال : يكفيك الماء } \\
& \text { ولا يضرك أثره. أخرجه الترمذي. }
\end{aligned}
$$

Dalam kitab Bulugh al-Maram Ibnu Hajar menyatakan Hadis tersebut diriwayatkan oleh Imam al-Turmużi, akan tetapi setelah ditakhrij Hadis tersebut tidak ditemukan dalam kitab Sunan al-Turmuzi. Hadis tersebut ditemukan dalam riwayat Imam $\mathrm{Abu}$ Dawud dalam kitabnya Sunan Abu Dawud nomor 365 seperti yang telah dijelaskan al-Bassam dalam kitab Tawdih al-Ahkam. Beliau menyatakan:

$$
\text { لم يخرجه الترمذي وإنما أخرجه أبو داود }
$$

"Hadis tersebut tidak diriwayatkan oleh Imam al-Turmuzi, akan tetapi diriwayatkan oleh Imam Abu Dawud" c. Menjelaskan makna mufradah

Langkah seterusnya yang dilakukan al-Bassam sebelum mengistinbatkan hukum dari Hadis dalam kitab Tawdih al-Ahkam adalah menjelaskan makna mufradah dan kata yang sukar dalam Hadis berkaitan dengan pengertiannya secara etimologi dan terminologi dan dari segi kaidah bahasa Arab. Poin ini ditandai dengan kalimat mufradat al-Hadis.

Penjelasan makna mufradah tidak dilakukan kepada semua lafazh yang terdapat dalam Hadis. Penjelasan tersebut hanya dilakukan pada lafazhlafazh tertentu yang menurut alBassam memerlukan penjelasan secara khusus. Terkadang beberapa lafazh dijelaskan kembali walaupun sudah dijelaskan sebelumnya agar tidak merepotkan pembaca untuk mengetahui maknanya.

Sebagai contoh, di antaranya terdapat pada Hadis ke-51 Kitab alTaharah, Bab al-Wudu' sebagaimana pada Hadis berikut ini:

$$
\begin{aligned}
& \text { عَنْ أَنَسِ قَالَ كَانَ النَّبٌٌُ -صلى الله عليه وسلم - }
\end{aligned}
$$

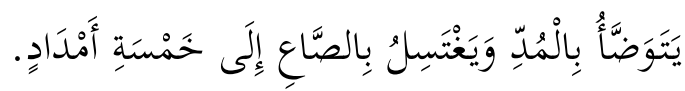

$$
\begin{aligned}
& \text { مفردات الحديث : } \\
& \text { الصاع مكيال معروف, والمراد به الصاع النبوي ويبلغ } \\
& \text { وزنه (.ییء) مثقال من البر الجيد وبا للتر (r لترات) } \\
& \text { المد بضم الميم, مكيال معروف وهو ربع الصاع } \\
& \text { النبوي ويجمع على أمداد ومدد ومقداره ( . vo ملل) }
\end{aligned}
$$

Pada Hadis di atas terdapat dua kata yang secara khusus dijelaskan oleh al-Bassam yaitu al-sa' dan amdad jamak dari kata mudd. Kedua istilah ini dikenal sebagai nama timbangan atau 
sukatan yang digunakan pada masa Rasulullah SAW $A l$-sa' maksudnya adalah sebagaimana dijelaskan alBassam adalah sa', Nabi SAW (al-Sa' alNabawi) yang beratnya setara dengan 3 liter. Sedangkan mud adalah $1 / 4 s a^{\prime}$ nabi atau setara dengan $750 \mathrm{ml}$. Untuk lebih jelasnya dapat dilihat pernyataan alBassam pada gambar berikut:

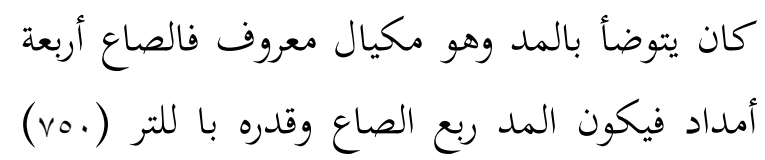

Metode istinbat hukum dalam arti mengeluarkan hukum dari nash tidak terlepas dari pendekatan dalam memahami Hadis. Secara garis besar ada dua tipologi pemahaman ulama terhadap Hadis, yaitu tekstual dan konteksual. Pendekatan tekstual adalah metode pemahaman terhadap Hadis Nabi Muhammad SAW Tanpa memperhatikan proses sejarah yang melahirkannya. Dalam pengertian lain, pendekatan tekstual adalah memahami Hadis berdasarkan makna lahiriah atau sesuai dengan arti secara bahasa. Pendekatan ini menurut teori Ma'ruf al-Dawalibi disebut dengan metode bayani.

Melalui pendekatan tekstual atau kebahasaan para peneliti dapat mengetahui dan memahami makna gharib yang terdapat dalam Hadis dan memahami makna dan tujuan Hadis. Karena Hadis menggunakan bahasa Arab maka langkah pertama yang harus dilakukan oleh para pengkaji adalah memahami kata-kata sukar. (Suryadilaga, 2012)

Sedangkan pendekatan kontekstual adalah memahami Hadis-Hadis
Rasulullah SAW dengan memperhatikan dan mengkaji keterkaitannya dengan peristiwa atau situasi yang melatarbelakangi munculnya, dengan kata lain memperhatikan dan mengkaji konteksnya. (Safri, 2013) selain dari pada itu memperhatikan sesuatu yang melatarbelakangi munculnya Hadis, posisi Nabi sebagai hakim, pemimpin Negara atau manusia biasa juga perlu diperhatikan ketika menggunakan pendekatan kontekstual.

Pengertian di atas menunjukkan bahwa terdapat dua cara yang bisa digunakan untuk memahami Hadis dengan menggunakan pendekatan kontekstual, yaitu menganalisa lafazh yang terdapat dalam teks dan mengaitkan dengan situasi yang berhubung kait dengan kejadian atau memahami dengan baik sebab yang melatarbelakangi munculnya suatu Hadis (asbab al-wurud).

Pendekatan kontekstual dalam memahami Hadis Nabi perlu dilakukan untuk menjawab persoalan-persoalan masyarakat yang semakin kompleks. Bahkan menurut Imam Syafi'i sebagaimana dikutip oleh Edi Safri pendekatan kontekstual merupakan salah satu metode menyelesaian Hadis mukhtalif. Namun demikian, pendekatan kontekstual tidak bisa diterapkan pada semua Hadis, hanya terbatas pada HadisHadis yang berbicara tentang ibadah ghair mahdah.

Kedua pendekatan tersebut digunakan oleh al-Bassam dalam memahami Hadis untuk meng-istinbatkan hukum dalam kitab Tawdih alAhkam. Contoh istinbat hukum alBassam dengan menggunkan pendekatan tekstual dapat dilihat di antaranya pada Hadis berikut: 
Hadis tentang larangan hidup membujang

$$
\begin{aligned}
& \text { عن أنس بن مالك قال : كان رسول الله صلى الله } \\
& \text { عليه و سلم يأمر بالباءة وينهى عن التبتل نهيا شديدا } \\
& \text { ويقول تزوجوا الودود الولود اني مكاثر الأنبياء يوم } \\
& \text { القيامة }
\end{aligned}
$$

“Dari Ānas bin Malik, ia berkata: Rasulullah SAW menyuruh untuk menikah dan melarang keras hidup mem-bujang dan berkata: Nikahilah wanita yang penyayang lagi subur. Sesungguhnya aku merasa bangga dengan banyaknya umatku pada hari kiamat". (H. R. Imam Ahmad)

Di antara makna tekstual Hadis tersebut sebagaiman dijelaskan alBassam adalah larangan hidup membujang. Ini dipahami dari lafazh al-tabattul pada Hadis tersebut. Makna kata tersebut adalah al-inqita', yaitu memutuskan. Al-Bassam dalam syarahnya menyatakan maksud al-tabattul adalah al-inqita'an al-zawaj (memutuskan diri dari pernikahan). (Safri, 2013)

Setersunya, makna tekstual dari Hadis di atas adalah perintah menikahi wanita penyayang dan subur (al-wadud al-walud). Berkenaan dengan makna ini al-Bassam menyatakan:

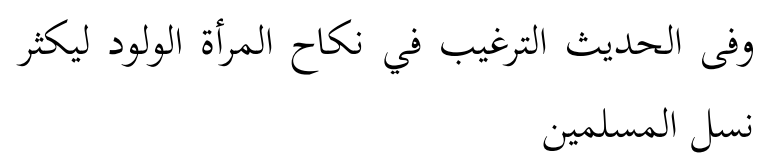

“Dalam Hadis dijelaskan dorongan untuk menikahi wanita yang subur untuk memperbanyak generasi Muslim". (Safri, 2013)

Selain pendekatan tekstual, pendekatan kontekstual juga digunakan alBassam dalam memahami Hadis untuk mengistinbatkan hukum dalam kitab Tawdih al-Ahkam. Di antara contohnya adalah dalam Hadis berikut ini:

Hadis tentang anjuran menikah bagi yang sudah mampu

$$
\begin{aligned}
& \text { عَنْ عَبْدِ اللَّهِ قَالَ قَالَ لَنَا رَسُولُ اللَّهِ -صلى الله عليه }
\end{aligned}
$$

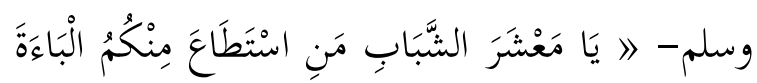

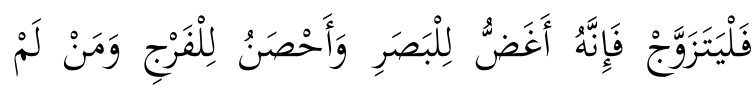

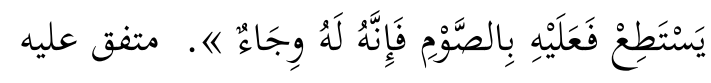

"Dari 'Abdullah ia berkata: Rasulullah SAW bersabda: Wahai para pemuda! Siapa di antara kamu yang sanggup ba'ah maka menikahlah, karena menikah memelihara pandangan dan menjaga kehormatan. Dan siapa yang belum sanggup maka hendaklah berpuasa, karena puasa adalah perisai". (H.R. Imam al-Bukhari dan Muslim)

Di antara pendekatan yang bisa digunakan dalam memahami Hadis dengan metode kontekstual adalah menganalisa lafazh yang terdapat dalam teks. Hal ini dilakukan oleh alBassam dalam kitab Tawdih al-Ahkam di antaranya pada kata al-ba'ah yang terdapat pada Hadis di atas. Kata al$b a^{\prime} a h$ memiliki dua makna, yaitu al-jima' (berhubungan suami isteri) dan $m u^{\prime} n$ al-nikah (biaya pernikahan). Tetapi maknanya yang lebih kuat menurut beliau adalah $m u^{\prime} n$ al-nikah. Sehingga maksud istita'ah menurut al-Bassam adalah mampu memenuhi biaya pernikahan seperti mahar dan belanja rumah tangga. Jika demikian, maka dianjurkan dan disunnahkan untuk melangsungkan pernikahan. Karena makna amar dalam Hadis di atas menurut para ulama termasuk alBassam adalah Sunnah. Al-Bassam 
mengatakan, perintah menikah bagi yang mampu adalah Sunnah menurut jumhur ulama (al-amr bi al-nikah liman istata'ah huwa 'ala sabil al-nadab).

Seterusnya, makna kontekstual lain dari Hadis di atas adalah kewajiban membayar mahar dan belanja isteri dibebankan pada suami. AlBassam menjelaskan:

$$
\begin{aligned}
& \text { يفهم من الحديث وجوب المهر ونفقة الزوجة على } \\
& \text { الزوج فإنه المخاطب بذالك }
\end{aligned}
$$

"Dipahami dari Hadis tersebut bahwa kewajiban membayar mahar dan belanja isteri ada pada suami".

\section{ISTINBAT AL-BASSAM TERHADAP PERSOALAN-PERSOALAN IKHTILAF}

Pada bagian pendahuluan, alBassam menyatakan bahwa dalam menetapkan hukum terhadap persoalanpersoalan ikhtilaf beliau tidak ta'assub atau cenderung kepada mazhab tertentu. Akan tetapi beliau berpegang kepada dalil dan pendapat para ulama yang lebih kuat. Langkah-langkah yang dilakukan alBassam terhadap permasalahan ikhtilaf adalah memaparkan pendapat para ulama ('ard al-aqwal), mempertentangkan dalil yang digunakan oleh setiap kelompok (munaqasyah al-adillah) dan melakukan altarjih\} atau memilih salah satu pendapat tersebut yang lebih kuat. Penjelasan ini menjawab dan membuktikan pernyataan al-Bassam bahwa dalam menetapkan hukum beliau tidak fanatik mazhab.

Terdapat beberapa persoalan ikhtilaf pada Kitab al-Nikah dalam Kitab Tawdih alAhkam sebagaima akan diuraikan pada penjelasan berikut ini: a. Pernikahan seorang laki-laki dengan seorang wanita yang sedang dalam pinangan orang lain.

Perbedaan pendapat para ulama dan pandangan al-Bassam tentang masalah ini dijelaskan pada pernyataan berikut.(Al-Bassam, n.d.-a)

$$
\begin{aligned}
& \text { خلاف العلماء : } \\
& \text { قال شيخ الإسلام : اتفق الأئمة الأربعة على تحريم } \\
& \text { الخطبة على خطبة الرجل وتنازعوا في صحة نكاح } \\
& \text { الثاني على قولين : } \\
& \text { أحدهما : ذهب مالك إلى أنه باطل وهي إحدى } \\
& \text { الروايتين عن أحمد. } \\
& \text { الثاني أنه صحيح. وهو مذهب الأئمة الثلاثة, مع } \\
& \text { اتفاقهم على أن فاعل ذالك عاص لله ولرسوله } \\
& \text { صلى الله عليه وسلم وتجب عقوبته. }
\end{aligned}
$$

Dalam pernyataan di atas terdapat dua pendapat ulama berkenaan status pernikahan seorang lakilaki dengan perempuan yang sedang dalam pinangan pria lain. Pendapat pertama mengatakan pernikahan tersebut batal, ini pendapat Imam Malik. Sedangkan menurut pendapat kedua pernikahan tersebut sah, akan tetapi pelakunya berdosa dan wajib mendapatkan sanksi, ini pendapat Imam Hanafi, Syafi'i dan Ahmad bin Hanbal.

Terkait dengan persoalan ini, alBassam mengatakan jika seseorang meminang lalu menikahi perempuan yang sedang dalam pinangan orang lain maka akadnya tetap sah, karena pengharaman dalam hal ini tidak berkaitan dengan akad (li ann al-tahrim laisa fi sulb al-'aqd). Dalam persoalan ini, 
pendapat al-Bassam sama dengan pendapat tiga Imam mazhab sebagaimana dalam penjelasan di atas.

b. Status saksi dalam pernikahan

Status keberadaan saksi sebagai salah satu syarat sah pernikahan menjadi perbedaan pendapat di Imam mazhab. Hal ini dapat dilihat dalam pernyataan al-Bassam berikut:

$$
\begin{aligned}
& \text { خلاف العلماء : } \\
& \text { إختلف العلماء فى اشتراط الشهادة لصحة النكاح : } \\
& \text { فذهب إلى اشتراطها جمهور العلماء, ومنهم الأئمة } \\
& \text { الثلاثة أبو حنيفة والشافعي وأحمد, وهو قول عمر إنى } \\
& \text { وعلي وابن عباس وسعيد بن المسيب وجابر بن زيد }
\end{aligned}
$$

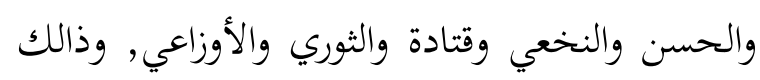

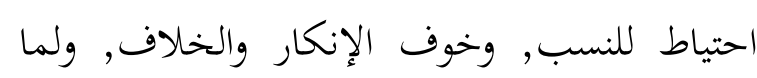

$$
\begin{aligned}
& \text { روى الدارقطني عن عائشة قالت : قال رسول الله } \\
& \text { صلى الله عليه وسلم : لا نكاح إلا بولي وشاهدي }
\end{aligned}
$$

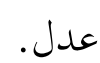

$$
\begin{aligned}
& \text { وذهب الإمام مالك ورواية عن الإمام أحمد اختارها } \\
& \text { شيخ الإسلام إلى أنه إذا أعلن النكاح فلا يشترط } \\
& \text { الشهادة, وطعنوا في صحة الحديث, فقد قال ابن إن إن إن } \\
& \text { المنذر : لا يثبت في الشاهدين خبر. } \\
& \text { قال الشيخ تقي الدين : لا يشترط في صحة النكاح }
\end{aligned}
$$

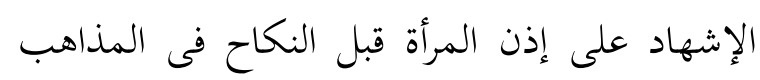

$$
\begin{aligned}
& \text { الأربعة, بل إذا قال الولي : أذنت لي جاز عقد الديل } \\
& \text { النكاح }
\end{aligned}
$$

Pernyataan di atas menjelaskan bahwa terdapat dua kelompok ulama yang berbeda pendapat tentang status saksi dalam pernikahan. Pendapat pertama adalah pendapat Imam Abu Hanifah, Imam Syafi'i dan Imam Ahmad bin Hanbal. Mereka berpendapat keberadaan saksi merupakan syarat sahnya pernikahan. Tanpa kehadiran saksi yang adil maka pernikahan tidak sah. Pendapat kedua adalah Imam Malik dan didukung oleh Ibn Taimiyyah. Menurut beliau saksi tidak menjadi syarat dalam akad pernikahan.

Pendapat yang dipilih al-Bassam sebagai hasil istinbatnya berkenaan dengan persoalan ini adalah pendapat jumhur ulama yang menyatakan bahwa keberadaan saksi menjadi syarat sah dalam akad pernikahan. Al-Bassam mengatakan tidak sah pernikahan tanpa kehadiran dua orang saksi lakilaki yang adil dan mukallaf (fala yasihh al-nikah illa bihadrah syahidain zakarain 'adlain mukallafain). (Al-Bassam, n.d.-a)

c. Status wali sebagai syarat sah pernikahan

Sebagaimana saksi, posisi wali dalam akad pernikahan juga menjadi perbedaan pendapat dikalangan para ulama. Ada yang menyatakan menjadi syarat sah pernikahan ada yang tidak. Perbedaan pandangan tersebut terdapat dalam pernyataan al-Bassam berikut:

$$
\begin{aligned}
& \text { خلاف العلماء : } \\
& \text { تقدم أن الولي شرط لصحة عقد النكاح, وأم هذا } \\
& \text { مذهب جمهور العلماء ومنهم الأئمة الثلاثة. } \\
& \text { وذهب الإمام أبو حنيفة وأتباعه إلى أنه لا يشترط. } \\
& \text { وحجتهم أدلة كثيرة وهي مسألة خلافية طويلة. }
\end{aligned}
$$




$$
\begin{aligned}
& \text { ومن أدلتهم قياس النكاح على البيع, فإن للمرأة أن } \\
& \text { تستغل وتبيع ما تشاء من مالها, فكذالك لها أن } \\
& \text { تزوج نفسها, لكن قال العلماء : إنه قياس فاسد } \\
& \text { لثلاثة أمور : }
\end{aligned}
$$

الأول : أنه قياس في مقابلة النص, وهذأ لا يجوز ولا يعتبر أصوليا. الناني : انه يشترط المماثلة بين

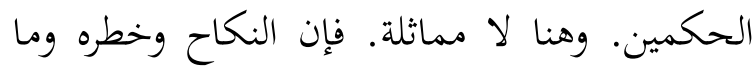
يحتاج إليه من نظر ومعرفة للعواقب يخالف البيع في بساطته وخفة أمره وضعف شأنه. الثالث : أن عقد النكاح على بعض الأزواج قد يكون مسبة وعارا على الأسرة كلها وليس على الزوجة وحدها, فأولياء أمرها لهم حظ من الصهر طيبا أو ضدة.

Pernyataan di atas dengan jelas menyatakan bahwa pendapat jumhur ulama termasuk di antaranya Imam Malik, Imam Syafi'i dan Imam Ahmad (al-a'immah al-salaśah), wali menjadi syarat sah akad pernikahan. Sedangkan ulama yang tidak menjadikan wali sebagai syarat sah pernikahan adalah Imam Hanafi dan pengikutnya.

Hasil istinbat al-Bassam berkenaan dengan persoalan ini adalah wali menjadi syarat sah akad pernikahan (alwali fi al-nikah syart li sihhatih). (AlBassam, n.d.-a) kemudian al-Bassam ketika mengistinbatkan hukum dari Hadis yang membahas tentang nikah tidak sah tanpa wali. Pendapat ini sesuai dengan pendapat jumhur ulama.

Izin wanita gadis yang sudah dewasa (al-Bikr al-Balighah) untuk menikah. Para ulama berbeda pendapat berkaitan izin wanita gadis yang sudah dewasa untuk dinikahkan. Pendapat yang masyhur dikalangan Mazhab
Hanabilah, mazhab maliki dan syafi'i adalah tidak perlu izin (li abiha ijbaruha). Ayah atau walinya memiliki hak penuh untuk menikahkannya. Sedangkan menurut mazhab hanafi dan dikuatkan oleh syeikh Taqy al-Din mesti minta izin. Perbedaan pendapat ini diuraikan dalam pernyataan alBassam di bawah ini:

$$
\text { خلاف العلماء : }
$$

ليس هناك نزاع بين العلماء في أن البالغة العاقلة الثيب لا تجبر على النكاح, ودليل ذالك واضح من النصوص. وليس هناك نزاع أيضا في أن البكر التي دون التسع ليس لها إذن فلأبيها تزويجها بكفئها بلا إذنها ولا رضاها. قال شيخ الإسلام : فإن أباها يزوجها ولا إذن لها. ودليلهم زواج عائشة رضي الله عنها من النبي صلى الله عليه وسلم وهي ابنة ست. واختلفوا فى البكر البالغة :

فا المشهور من مذهب الإمام أحمد : أن لأبيها إجبارها, وهو مذهب مالك والشافعي وإسحاق.

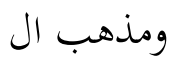
ومذهب الإمام أبي حنيفة والرواية الأخرى عن الإمام أحمد عدم اجبار المكلفة بكراكانت أو ثيبا, اختاره أبو بكرعبد العزيز والشيخ تقي الدين, قال فى الفائق : وهو الأصح.

Pendapat al-Bassam berkaitan dengan permasalahan ini adalah seorang ayah yang ingin menikahkan anak gadisnya yang sudah dewasa (albikr al-balighah) harus minta izin terlebih dahulu. Al-Bassam mengatakan dilarang menikahkan wanita gadis sebelum dapat izin (al-nahy 'an nikah albikr qabl isti'zaniha). (Al-Bassam: 270) 
Pendapat ini sesuai dengan pendapat mazhab hanafi dan syeikh Taqy al-Din seperti dalam pernyataan di atas.

d. Status merdeka dijadikan sebagai mahar

Persoalan lain yang menjadi ikhtilaf ulama pada Kitab al-Nikah dalam kitab Tawdih al-Ahkam adalah menjadikan kemerdekaan budak sebagai mahar (ja'l al-'itq sadaqan). Ulama yang membolehkannya dijadikan mahar pernikahan adalah Imam Ahmad bin Hanbal. Sedangkan ulama yang tidak membolehkannya adalah Imam Hanafi, Imam Malik dan Imam Syafi'i. Menurut mereka, Hadis tentang Rasulullah SAW memerdekakan Safiyyah dan menjadikannya sebagai mahar pernikahan merupakan khususiyyah bagi Nabi SAW tidak berlaku bagi umatnya. Permasalahan ini dijelaskann dalam pernyataan al-Bassam berikut ini:

$$
\begin{aligned}
& \text { خلاف العلماء : } \\
& \text { اختلف العلماء في جواز جعل العتق صداقا. } \\
& \text { فذهب الإمام أحمد وإسحاق : إلى جوازه, عملا } \\
& \text { بقصة زواج صفية وبأنه القياس الصحيح, لان السيد }
\end{aligned}
$$

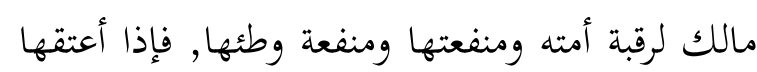

$$
\begin{aligned}
& \text { واستبقى شيأ من منافعها التي هي تحت تصرفه فما } \\
& \text { المانع من ذالك وما هو المحذور؟ } \\
& \text { وذهب الإمام الثلاثة : إلى عدم زواز ذالك, وتأولوا }
\end{aligned}
$$

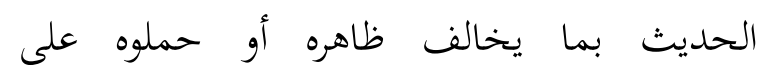

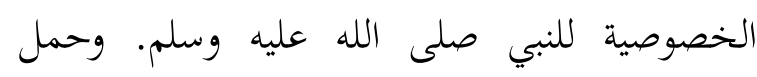

$$
\begin{aligned}
& \text { الحديث على خلاف ظاهره أو جعله خاصا يحتاج } \\
& \text { إلى بيان ودليل, لأن الأصل بقاء الحديث على }
\end{aligned}
$$

الظاهر كما أن الأصل فى الأحكام العموم, ولو كان خاصا لنقل.

Istinbat al-Bassam berkaitan persoalan di atas adalah sesuai dengan pendapat Ahmad bin Hanbal. AlBassam mengatakan:

$$
\text { وتكون زوجته عتق الرجل أمته وجعل عتقها صداقا لها }
$$

"Seseorang boleh memerdekakan hamba perempuannya dan menjadikan merdekanya sebagai mahar dan sah menjadi isterinya". (Al-Bassam, n.d.-b)

Pendapat al-Bassam ini sama dengan pendapat Ahmad bin Hanbal bukan karena beliau panatik terhadap ulama perintis mazhab hanabilah tersebut, akan tetapi karena berpegang kepada tekstual Hadis tentang Rasulullah SAW memerdekakan Safiyyah kemudian menikahinya dan menjadikan merdekanya sebagai mahar. Dengan demikian dapat dibuktikan bahwa al-Bassam bukan ulama yang fanatik mazhab.

\section{KESIMPULAN}

Berdasarkan penjelassan di atas, bahwa al-Bassam mengistinbatkan hukum dari Hadis-Hadis dalam kitab Tawdih alAhkam dengan menggunakan metode bayani (tekstual) dan istislahi (kontekstual) kemudian menggunkan pendekatan yang sistematis, yaitu mengemukakan takhrij Hadis, menjelaskan kualitas Hadis, menjelaskan makna mufradah dan menjelaskan hukum yang terkandung dalam Hadis. Berkenaan dengan penyelesaian persoalan ikhtilaf, al-Bassam mengguna- 
44

kan tiga metode, yaitu 'ard al-aqwal, munaqasyah al-adillah dan al-tarjih. Sedangkan berkenaan dengan persoalan kontemporer al-Bassam tidak merumuskan pendapat atau metode tersendiri, akan tetapi beliau mengemukakan pendapat para ulama. Walaupun alBassam beraliran mazhab hanbali, namun dalam menetapkan hukum beliau tidak fanatic mazhab, beliau berpegang kepada dalil dan pendapat para ulama yang dinilai lebih kuat. Penelitian ini diharapkan dapat memberikan sumbangsih pemikiran kepada mereka yang ingin memperdalam pengetahuan tentang syarah Hadis dan istinbat hukum sehingga dapat melahirkan pemahaman Hadis yang salih likulli zaman wa makan.

\section{DAFTAR PUSTAKA}

Al-Asy'as, A. D. S. (n.d.). Sunan Abu Dawud. Dar al-Kitab al-'Arabi.

Al-Bassam, 'Abdullah bin 'Abdurrahman bin Salih. (n.d.-a). awdih al-Ahkam Min Bulugh al-Maram. Maktabah alAsadi.

Al-Bassam, 'Abdullah bin 'Abdurrahman bin Salih. (n.d.-b). Taisir al-'Allam Syarh 'Umdah al-Ahkam, Tahqiq: Muhammad Subhi bin Hasan Hallaq. Maktabah al-Sahaabah.

Al-Kaf, I. H. (1998). Ijtihad Menjawab Tantangan Zaman. Ramdhani.
Al-Qardawi, Y. (1993). Syari'ah al-Islam Salih li al-Tatbiq fi Kulli Zaman wa Makan. Dar al-Sakhwah.

Al-Salih, S. (1984). 'Ulum al-Hadis wa Mustalahuh. Dar al-'Ilm li al-Malayin.

Al-Wahbi, F. bin M. (n.d.). Manhaj Istinbat Min al-Qur'an al-Karim. Silsilah Rasa'il al-Jami'iyah.

Al-Zarqani, M. 'Abd al-'Azim. (n.d.). Manahil al-'Irfan. 'Isa al-Bab alHalabi.

Anas, M. bin. (n.d.). al-Muwatta',. T.tp.

Muhajir, N. (1996). Metode Penelitian Kualitatif. Rakesarasin.

Rahmawati. (2015). Istinbath Hukum. Deepaublish.

Safri, E. (2013). Metode Penyelesaian HadisHadis Mukhtalif. Hayfa Press.

Soedjono. (1999). Bentuk Penelitian: Suatu Pemikiran dan Penerapan. Rineka Cipta.

Somantri, G. R. (2005). Memahami Metode Kualitatif. Makara, Vol. 9, No.

Suryadilaga, A. (2012). Metodologi Syarah Hadis. Suka Press.

Yahya, M. (1986). Dasar-Dasar Pembinaan Hukum Fiqih Islam. al-Ma'arif.

Zed, M. (2008). Metode Penelitian Kepustakaan. Yayasan Obor Indonesia. 